CZU:81'25+004.8

https://doi.org/10.52505/filomod.2021.15.27

\title{
TRADUCEREA ÎNTRE TRANSFERUL COMPLEXITĂȚII ȘI PRACTICILE INTELIGENȚEI ARTIFICIALE
}

\author{
Miroslava MetLeaeVA (LUCHIANCICOVA) \\ Institutul de Filologie Română „B. P.-Hasdeu” al MEC
}

Rezumat. Analizând situația respectivă, se observă lucruri care ridică semne de intrebare, referitoare la diversele teorii și practici ale traducerii, legate de criteriile de realizare acestui proces. Autorul demonstrează diferența dintre operațiile mentale ale Inteligenței Artificiale și ale omului în procesul de traducere. Sunt demonstrate câteva distincții esențiale din contribuția coșeriană în teoria traducerii, care se regăsesc în abordările teoretice actuale. Interpretarea gândirii autorului este legată de gândirea traducătorului și de toate componentele psihosociale și istorice al ambilor. Gândirea tehnică ca parte aplicativă a gândirii volumetrice imprevizibile are tendința de a raționaliza, sistematiza și reglementa. Acelaşi lucru se aplică sferelor științifice și tehnice ale limbajului care nu tolerează sinonimizarea, adică varietatea. Intregul complex de recunoaștere și decodificare a capacității comunicative umane este inaccesibilă mașinii, adică Intelectului Artificial. Presiunea puterii, din punctul de vedere autorului, asupra procesului de traducere este unul dintre pașii pentru stăpânirea procesului de gândire în general.

Cuvinte-cheie: traducerea, diferența mentală, Inteligența Artificială, polisemie, gândirea tehnică, varietatea.

Abstract. Analyzing the respective situation, we observe things that raise questions, referring to the various theories and practices of translation, related to the criteria for carrying out this process. The author demonstrates the difference between the mental operations of Artificial Intelligence and man in the translation process. Some essential distinctions from Coseriu's contribution to translation theory are demonstrated, which are found in current theoretical approaches. The interpretation of the author's thinking is related to the translator's thinking and to all the psychosocial and historical components of both. Technical thinking as an applicative part of unpredictable volumetric thinking tends to rationalize, systematize and regulate. The same applies to the scientific and technical spheres of language that do not tolerate synonymy, ie variety. The whole complex of recognition and decoding of human communicative capacity is inaccessible to the machine, ie the Artificial Intellect. The pressure of power, from the author's point of view, on the translation process is one of the steps for mastering the thought process in general.

Keywords: translation, mental difference, Artificial Intelligence, polysemy, technical thinking, variety. 
Traducerea e un proces „,post-factum”, un proces de transpunere a unui text literar original într-un spațiu cultural-informațional străin și în haina altei limbi. Dar această secundaritate a traducerii e paradoxală, deoarece întregul paradox se reduce la faptul că în esența sa cultural-informațională orice transpunere integrală a originalului literar e primară, ea neavând în limba inițială nicio analogie, chiar și în pofida faptului că mai există și alte traduceri ale aceluiași text original. Cauza acestei situații paradoxale rezidă in faptul că fiecare traducere poartă asupra sa amprenta personalității unui traducător concret și, la o adică, a mediului său temporal.

Traducerea este axată pe text, care este scopul, obiectul și finalitatea traducerii. Acest proces poate fi interpretat drept o transformare în cea de a doua realitate materială a operei poetice originale, înveșmântată în haina altei limbi, dar care a păstrat spiritul și, în măsura posibilităților, artisticul originalului.

Analizând situația respectivă, observăm lucruri care ridică semne de întrebare, referitoare la diversele teorii și practici ale traducerii, legate de criteriile de realizare ale acestui proces.

În Programul european în domeniul științei și tehnologiei COST (European Cooperation in Sciense \& Tehnologie) $\mathrm{m}$-a interesat directia Limba în epoca omului-mașina(CA19102 Language in the HumanMachine Era pag. 4): „În următorii 10 ani, multe milioane de oameni vor ... purta dispozitive relativ discrete ... care oferă o lume captivantă și vizual lărgită”. ...Limbajul pe care îl vedem, auzim și producem va fi mediat în timp real de tehnologie. Acest lucru are implicații majore pentru utilizarea limbajului și, în cele din urmă, pentru limbajul însuși. Sunt lingviștii pregătiți pentru asta? Teoria, metodele și epistemologia noastră sunt capabile să facă față?” (COST, 2020)

Într-o oarecare măsură, autorii proiectului au identificat consecințele etice ale limbajului tehnologic: inegalitatea accesului la tehnologie, confidențialitate și probleme de securitate, noi vectori pentru înșelăciune și criminalitate etc.

În psiholingvistică există conceptul unui text precedent, adică un text cunoscut culturii și la care există referințe în vorbire. O referință poate să nu fie transformată și poate fi transformată, până la o singură componentă - un cuvânt, crescând sarcina semantică a textului și activând cititorul (în cazul nostru, traducătorul).

Dacă abordăm problema traducerii mai amplu, atunci ajungem la concluzia că capacitatea de a traduce este o însușire universală a gândirii umane. Înainte de a pune gândul în formă de vorbire, are loc un proces mental, a cărui secvență, în opinia noastră, este următoarea: formă de gândire amorfă $>$ idee-gândire $>$ gând-text $>$ traducere (transmitere) în limba sursă pentru schimbul comunicativ.

Nicio mașină nu va putea rezolva vreodată problemele cu care se confruntă autorul ca prim traducător al propriei sale idei de gândire dintr-o 
formă de gândire amorfă în limba sa maternă. Nicio mașină nu poate face față sarcinilor cu care se confruntă traducătorul textului literar din limba sursă în limba primitoare. Transmiterea gândirii ample a autorului este asociată cu coduri atât ale sursei, cât și ale limbii primitoare. Interpretarea gândirii autorului este legată de gândirea traducătorului și de toate componentele psihosociale și ale mediului temporal-spațial al ambilor.

A. M. Finkel încă în anii 30 al secolului trecut în articolul Cu privire la unele aspecte ale teoriei traducerii și-a exprimat poziția privind construirea unei teorii a traducerii, care, din punctul nostru de vedere, este actuală și astăzi: „,este imposibil de a construi o teorie a traducerii comună pentru toate epocile, limbile, genurile și stilurile literare. Această «teorie» va fi abstractă și moartă. Teoria traducerii științifice trebuie să se bazeze pe lingvistică ca o teorie a posibilităților de limbă (limita inferioară și superioară) în manifestările lor socio-culturale și istorico-literare specifice.”(Aizenștok, 1970, p. 110).

In filosofia postmodernismului, fenomenul puterii limbajului este analizat pe larg. Conform conceptului lui R. Barthes, teoretic sunt posibile doar două variante alternative ale corelației puterii și limbajului: cooperarea limbii cu guvernul și opoziția sa față de acesta - neutralitatea lingvistică în ceea ce privește puterea, potrivit lui R. Barthes, este în principiu imposibilă, ,unele limbi vorbesc, se dezvoltă, își însușesc trăsăturile caracteristice în lumina (sau sub adăpost) ale Autorității ... Alte limbi sunt dezvoltate, dobândite, înarmate în afara Autorității și/sau împotriva acesteia" (Barthes, 1984). În terminologia lui R. Barthes, limbile de primul tip sunt desemnate ca „limbaje encratice” (care corespund „tipurilor de discurs encratic”), limbile de al doilea tip sunt denumite „acratice” (și, respectiv, „tipuri de discurs acratic") (Barthes, 1984).

Limba encratică, din punctul nostru de vedere, este unul dintre pașii pentru stăpânirea procesului de gândire, dacă este imposibil să-1 reproducem integral într-o versiune artificială a mașinii-creier. Adică, dacă este imposibil să controlezi procesele de gândire din interior, atunci este mult mai ușor să le influențezi din exterior.

R. Barthes menționează: „De altfel, limbajul encratic (cel care apare și se răspândește sub protecția puterii) este prin natura sa un limbaj repetitiv; toate instituțiile lingvistice oficiale sunt mașini care mestecă în mod constant aceeași gumă: școală, sport, publicitate, cultură de masă, producție de cântece, surse mass-media reproduc non-stop aceeași structură, același sens și, uneori, aceleași cuvinte: stereotipul este un fenomen politic, este chiar întruchiparea ideologiei(Barthes, 1989, p. 494).”

Aceste idei se vehiculează de mult în literatura universală. O declarație rigidă a fenomenului respectiv, inerent viitoarei „societăţi a ideilor tehnologice”, care a dizolvat în sine absurditatea „societății de consum” și duce la lipsa totală de libertate, a fost formulată în 1948 de George Orwell în romanul-antiutopie 1984: „Scopul Nouvorbei nu este doar acela de 
a oferi un mijloc de exprimare concepției despre lume și obiceiurilor mentale proprii adepților devotați ai SOCENG-ului, ci, în același timp, de a face imposibil orice alt mod de gândire (SOCENG - abreviat din Socialismul Englez - ideologia statului utopic Oceania. Notat de M. M.) (Orwell, 2012, p. 331).

Având în vedere teoria traducerii proprie într-un context mai larg, savantul izraelian I. Even-Zohar demonstrează existența sistemului limitat al relațiilor dintre textele artistice traduse de anumit polisistemul literar, care par independente. Aceste relații se aplică și la principiile de stabilire a calitătii traducerii pe baza normelor literare ale limbii țintă.

În mod tradițional se consideră că traducerea ocupă întotdeauna o poziție periferică în polisistemul limbii țintă. I. Even-Zohar, având în vedere astfel de situație ,,periferică” destul de normală, determină 3 situații în care textul tradus ar putea ocupa locul central.

Prima dintre ele - o situație în care literatura „tânără” se găsește în procesul de formare și nu a fost încă dezvoltată într-un polisistem. În acest caz, autorii „tinerii” culturi se adresează la literaturi mai mature în căutare modelelor deja stabilite pentru diferite tipuri de texte. A doua situaţie acesta este cazul atunci când o literatură a unei națiuni mici este suprimată de literatura dominantă a națiunii mai mare. A treia situație este literatura care se află în curs de dezvoltare, în momente de crize culturale sau politice: vidul creat după moartea modelelor vechi se umple rapid cu un curent de idei și concepte noi, care pătrund în cultura limbii țintă prin traducere. (Even-Zohar, 1990)

A doua situație și, parțial, a treia sunt foarte cunoscute din perioada RSSM. „Activitățile de traducere din Republica Moldova, ca și toate activităţile, au fost limitate până în 1991. ... Studierea limbilor străine și funcționarea domeniilor relevante (predare, traducere etc.) au fost sub control constant (...), deoarece au fost legate de activități care ar putea avea un impact ideologic mare asupra grupurilor individuale sau asupra societății în ansamblu (...). Datorită cenzurii, jurnaliștii moldoveni au fost nevoiți să scrie la început articolele lor în limba rusă, iar abia apoi textul se traducea în limba „moldovenească” (Condrea, 2006, p. 24).

În ciuda numeroaselor tendințe transumaniste, toate urmăresc un singur scop - crearea unei persoane fără dezabilități fizice. Dar practic nici unul dintre fondatorii acestor concepte filosofice nu ridică problema locului emoțiilor, moralității, culturii în conștiința viitorului om.

Faptul este că pur și simplu ele nu sunt acolo: post-omul este reprezentat ca cea mai înaltă specie biotehnologică, a cărui conștiință se va baza pe Inteligența Artificială. Astfel, conceptele umane generale despre bine și rău, despre istorie, despre locul său în lume, despre relațiile cu alte persoane nu vor avea niciun sens pentru el, fiindcă omul-mașina va pierde o mare parte din experiența lui anterioară inutilă acum. 
Este ciudat să așteptăm de la o mașină - Inteligență Artificială că va gândi ca o persoană umană sau va fi ghidată de aceeași moralitate ca și homo sapiens.

Eugeniu Coșeriu este un nume prezent în cercetarea traductologică actuală, interesul pentru scrierile sale despre teoria traducerii se păstrează constant. Necesitate de stabilire a unor baze teoretice solide îl face pe Coșeriu să își înceapă demersul printr-o analiză critică a pozițiilor teoretice care îl duce la concluzia că majoritatea teoriilor enunțate fie nu ating problematica traducerii, fie sunt eronate, fie, dacă reprezintă un punct de vedere clar și bine fundamentat, sunt incomplete.

Coșeriu realizează câteva distincții esențiale în ceea ce privește teoria traducerii, distincții care se regăsesc și în abordările teoretice actuale. În virtutea celor afirmate, ne vom opri la o definiție pe care a dat-o traducerii Eugen Coșeriu: „Actul de traducere nu este altceva decât o vorbire, cu un conţinut virtual identic, în două limbi diferite. Nu traducem limbi, ci vorbiri și afirmații; nu traducem ceea ce o limbă dată ca atare spune, ci ceea ce să spune cu această limbă, nu traducem deci semnificații, ci, în principiu, traducem ceea ce este desemnat cu ajutorul semnificațiilor. Semnificațiile sunt un instrument și nu un obiect al vorbirii. Nu există o transpunere directă de la semnificațiile limbii-sursă către semnificațiile limbii-țintă; drumul trece în mod necesar prin desemnatul extralingvistic. De aceea traducerea este mai întâi «des-compunere prin limbaj» (Entsprachlichung) urmată de o «re-compunere prin limbaj» (Versprachlichung)" (Coșeriu, 1993, p. 36).

Savanta Cristina Varga, analizând contribuția coșeriană în teoria traducerii, notează: „Prin urmare, putem constata că cel mai des discutat concept este acela al perspectivei textuale asupra traducerii, conform căruia „nu traducem cuvinte ci traducem texte”. (Varga, 2017, p. 46). Pe fondul actualelor tendințe contradictorii în ceea ce privește teoria generală a traducerii, gândurile lui Eugen Coșeriu despre cele trei planuri ale limbajului și anume despre planul universal al vorbirii în general, planul istoric al limbilor, planul individual al discursului, sunt foarte relevante.

Incapacitatea percepției multidimensionale a realității se transformă inevitabil în indiferența tehnocraților, iar o astfel de indiferență e o demonstrație a absenței instrumentelor umanitare de diferență.

Purtătorii unui limbaj tehnocratic - un limbaj aplicat care nu are conținut emoțional, psihologic, etnic, etic etc., cel mai adesea sunt adepții puterii interesate de limitarea mecanicistă a conștiinței și de abordarea unei persoane de rând ca pe o mașină, obișnuindu-o cu ideea de a se îmbunătăţi cu ajutorul tehnologiilor și a beneficiilor legate de aceasta, care permit depășirea gândirii naturale și a altor abilităţi. De cele mai multe ori, se dau ca exemplu capacitatea computerelor moderne de a învinge într-un joc de șah sau în jocul chinezesc GO cu nenumărate combinații. De aici și încercările de a reduce totul (din interesele socio-economice) la un limbaj universal al numerelor, care nu conține componente emoționale, morale, culturale și istorice. Dar existența umană nu se limitează la jocuri, oricât 
de complexe ar fi acestea. Sunt, în primul rând, jocuri reglementate. Într-un fel sau altul, soluția pentru problemele jocului poate fi calculată cu ajutorul AlphaGo, programat oricum de un om.

Există condiții reale pentru o traducere satisfăcătoare a textelor tehnice, științifice, profesionale, adică a celor pentru care polisemia este contraindicată. $\mathrm{Cu}$ cât precizia terminologică și structurală este mai mare (cu absența trăsăturilor figurative și emoționale), care are și un caracter internațional, cu atât este mai înaltă calitatea traducerii automate, deoarece nu necesită de la mașină ceea ce ea nu poate - să fie om în sensul adevărat al cuvântului.

Când vine vorba de traducerea unui text-gând fără ambiguități, este necesară o astfel de abordare către traducerea sensului său atât în limba-sursă, cât și în limba-țintă. Dar dacă vorbim despre un mesaj care are precedent și alte aspecte figurative, atunci urmărind viteza activității, pierdem din expresivitatea artistică și, dacă mergem mai departe, din posibilitățile de autoexprimare creativă și dezvoltarea limbajului în ansamblu.

Prin reducerea propriului volum de gândire creativă, utilizatorul urmează reproducerea ei liniară în conformitate cu șabloane impuse de "gândire" automată. Așa se impune și se realizează treptat „educaţia" utilizatorului. Aceasta nu este victoria Inteligenței Artificiale, ci înfrângerea omului în căutarea iluziei propriei sale îmbunătățiri.

Istoria transumanismului mărturisește viziunea sa mecanicistă asupra vieții umane, și anume că o persoană este un dispozitiv, datoria sa este de a deveni o versiune cât se poate de îmbunătățită, adică transumanismul este o mișcare de eliberare care susține eliberarea completă a omului de biologie în sine. „Există o altă viziune asupra acestei chestiuni: o interpretare opusă echivalentă, și anume că o astfel de eliberare aparentă în realitate nu este altceva decât înrobirea finală și completă a omului de către tehnologii" (O’Konnell, 2019, p. 14).

\section{Concluzii:}

- Situația respectivă în domeniul teoriei și practicii ale traducerii demonstrează lucruri care ridică semne de întrebare, legate de criteriile de realizare acestui proces.

- Diferența dintre operațiile mentale ale Inteligenței Artificiale și ale omului în procesul de traducere artistică este un moment crucial în înțelegerea imposibilității de a reda aspectul volumetric al ideii prin surse tehnologie, deoarece cu toată dorința mașina nu poate să includă integral identitatea intelectuală naturală și imprevizibilă a omenirii.

- Sunt demonstrate câteva distincții esențiale din contribuția coșeriană în teoria traducerii, care se regăsesc în abordările teoretice actuale: vorba merge despre cele trei planuri ale limbajului și anume despre planul universal al vorbirii în general, planul istoric al limbilor, planul individual al discursului. 
- Gândirea tehnică ca parte aplicativă a gândirii volumetrice imprevizibile are tendința de a raționaliza, sistematiza și reglementa. Același lucru se aplică sferelor științifice și tehnice ale limbajului care nu tolerează sinonimizarea, adică varietatea. Întregul complex de recunoaștere și decodificare a capacității comunicative umane este inaccesibilă mașinii, adică Intelectului Artificial.

- Presiunea puterii, din punctul de vedere autorului, asupra procesului de traducere este unul dintre pașii pentru stăpânirea procesului de gândire în general. Tendința de prezentare a mostrelor factografice în lumina inoculatelor indicații ideologice se referă la aspectele psihologice de formare a gândirii conformiste, a potențialului intelect servil puterii și care cuprind domeniile culturii, educației, tehnologiilor informaționale. Se știe că orice deformare a realității peste o lungă perioadă de timp duce la consecințe neprevăzute și exercită un efect imprevizibil asupra mentalității noilor generații.

\section{Referințe bibliografice:}

1. AIZENȘTOK, Ieremia. A.M. Finkel - teoretik hudojestvennogo perevoda. În: Masterstvo perevoda. Sbornik cedimoi. Moskva. Sovetskii pisateli, 1970, p. 91-118.

2. BARTES, Roland. Voyna yazykov (La guerre des langages). Vystuplenie na simpoziume Le Conferenze dell'Associazione Italiana Culturale, 1973. Perevod vypolnen po izdaniyu Barthes R. Le bruissement de la langue, Seuil, 1984, p. 127-132. [on-line] https://redpsychology.wordpress.com / 2013/11/23 (vizitat la 07.09. 2021)

3. BARTES, Roland. Izbrannye raboty. Semiotika. Poetika. M., Sost., Obshch. red. i vstup. st. G. K. Kosikova. M.: Progress, 1989. $616 \mathrm{~s}$. $266 \mathrm{p}$.

4. Condrea I. Traducerea din perspectivă semiotică. Chișinău: Cartdidact, 2006.

5. COST www.cost.eu/cost-action/language-in-the-human-machine-era/

6. COȘERIU, Eugen. Semn, simbol, cuvânt. În: Analele Științifice ale Universității „Alexandru İoan Cuza”. Iași: Editura Universității „Alexandru Ioan Cuza”, 1993, tom. XXXIX, secț. 3 - lingvistică, p. 5-22.

7. EVEN-ZOHAR, Itamar. „Polysystem Studies, Poetics Today, capitolul „, The Position of Translated Literature within the Literary Polysystem”, Tel Aviv University, 1990, p. 45-51. http://transeurope.ru/publications/teoriya-polisistemyi-v-rabotah-i-evenzohara.html

8. O'KONNELL, Mark. Iskusstvennyy intellekt i budushchee chelovechestva. Moskva: Eksmo, 2019. 272 p.

9. VARGA, Cristina. Este actual Eugeniu Coșeriu în teoria traducerii?". În: Studii de traductologie românească. Discurs metatraductiv. Universitatea „Babeș-Bolyaill”, Cluj Napoca, 2017, p. 37-51.

Notă: Articolul a fost realizat în cadrul proiectului de cercetare 20.80009.1606.03 Contexte socioculturale autohtone şi interconexiuni europene în creaţia populară şi literatura cultă din Basarabia (sec. XIX până în prezent), Institutul de Filologie Română „B. P.-Hasdeu” al MEC. 